\title{
Life cycle assessment and leather production
}

\author{
Diego Navarro ${ }^{1,2}$, Jianhui $\mathrm{Wu}^{3}$, Wei $\operatorname{Lin}^{3^{*}}$ (D), Pere Fullana-i-Palmer ${ }^{4}$ and Rita Puig ${ }^{5^{*}}$
}

\begin{abstract}
Leather industry is facing new trends on production and consumption patterns due to society concerns. Circular economy is proposing a transition from the current economic model to a more sustainable one, in which waste is designed out and resources will be reused and recycled as long as possible. In this transition, Life Cycle Assessment (LCA) is an important tool to help decision-making. In the present review, 39 English-written peer-reviewed papers related to LCA and leather have been found, 30 of which were published in the last 6 years, meaning LCA is nowadays an important subject. Papers are presented within 4 types, focused on: 1) the whole leather production process, 2) a single step in the production process (e.g, new technologies for unhairing), 3) waste treatment and recycling, and 4) life cycle thinking with ideas on long-term strategies for leather industries. As discussed in the literature review, leather industry has important challenges to address: increasing sustainability and transparency on the supply chain, and strengthening the beauty of leather. Taking up these challenges from a life cycle perspective will help leather industry flourish in the coming future.
\end{abstract}

Keywords: Circular economy, Life cycle thinking, Inventory data, Tanning processes, Leather sustainability

\section{Introduction}

Leather was one of the most important materials in the human earliest times. Our ancestors hunted animals for food and used their hides for clothing, food and tents, to protect themselves from the elements. Leather production evolved during industrialization from the traditional vegetable-tanned leather (too hard and thick) to the modern chrome-tanned, which became the standard for footwear, fashion and upholstery. Since then, leather industry has innovated in the development of chemicals, new processing methods and the finished-leather properties [1,2].

During the last century, environmental concerns became more and more pressing, beginning with water pollution in the twentieth century, until a more global

\footnotetext{
* Correspondence: wlin@scu.edu.cn; rita.puig@udl.cat

${ }^{3}$ Department of Biomass and Leather Engineering, Key Laboratory of Leather Chemistry and Engineering of Ministry of Education, Sichuan University,

Chengdu 610065, China

${ }^{5}$ Department of Computer Science and Industrial Engineering, Universitat de Lleida (UdL), Pla de la Massa, 8, 08700 Igualada, Spain

Full list of author information is available at the end of the article
}

approach in the last decades. Initial environmental strong regulations in Europe, together with high labor costs, lead to a move of the leather production from industrialized to developing countries (Latin America, India or China). Rapid business growth in those countries created several environmental pollution problems (mainly affecting agriculture and accessibility to clean water). As a result, sustainability of leather industries was questioned [3]. This industry acted all around the world by innovating and addressing the main environmental concerns caused by their production processes (i.e., water consumption and wastewater treatment, solid-waste recovery and the avoidance or reduction of some chemicals like chromium, sodium sulfide, etc.) [4].

Nevertheless, nowadays society and markets are asking for a more holistic approach, where not only tannery processes are involved, but all its value chain. Traceability becomes very important (no child-labor, hides from animal-care farms, etc.) together with a circular economy, where resources are used sustainably [5].

Circular economy aims to help the society's change towards a new economy where production and 
consumption patterns need to be re-designed to avoid environmental impacts and maintain natural resources for as long as possible in the technosphere $[6,7]$. The current linear model (extraction of resources, production, use and landfilling) is not sustainable, as the resources are limited and there is an ever growing demand [8]. Efforts on deeper implementation of circular economy are being made in several industrial activities, such as agriculture and food [9-11], paper [12], textile [13, 14] or packaging $[15,16]$. Leather industry is also addressing these issues, as will be seen in the present paper.

Life cycle assessment (LCA) is a close related tool to circular economy. It helps to understand the materials and energy flows throughout the complete life cycle of a product, service or system (which may include technologies or organizations), and their related environmental impacts [17]. LCA takes a systemic and holistic approach, where all involved processes are studied. It can thus contribute to re-think and re-design products and processes $[18,19]$, and help on decision-making to choose among different waste treatments $[20,21]$ or to compare materials [22, 23], products [24, 25] and/or processes from an environmental point of view [26]. In addition, LCA is also useful to obtain and communicate traceability information. Therefore, it is of utmost importance for leather industries to address environmental research and innovation with an LCA type of approach for a long-term sustainability.

Herein, we provide an overview of the LCA studies related to leather production found in the scientific literature, namely English-language articles in peer-reviewed journals. The aim of the present paper is to introduce this scientific methodology applicable to quantify the environmental impact of leather production and further help the leather industry optimize or improve their technologies.

\section{Details on LCA methodology}

The LCA methodology is described in the standards ISO 14040 [27] and ISO 14044 [17]. It consists of 4 main steps (see Fig. 1): Goal and scope definition, inventory analysis, impact assessment and interpretation of the results.

In the goal and scope, the aim of the LCA study must be stated (i.e., an LCA comparing two different products or an LCA where we want to know the environmental hotspots in the life cycle of a product/service to improve it). Regarding the scope of the LCA, there are some studies where the analysis includes every step, from the production of raw materials until the end-of-life of the product ("from cradle to grave"), while others only consider the steps from raw materials to production of the product ("from cradle to gate"). Thus, the scope of the study should be visualized in the system boundaries (see Fig. 2 as an example). As shown in Fig. 2, the system boundaries of a "from cradle to gate" LCA of leather should include all upstream processes, such as farming and slaughtering, in addition to core processes (tannery) and all transports needed from one process to another. Impacts due to production of chemicals, energy and water used in our system and impacts due to waste and wastewater treatments should also be considered.

Finally, within the goal and scope, we need to choose the functional unit for the study. The functional unit is the reference to which all environmental impacts will be related. For example, in an LCA study of leather shoes,

\section{Life Cycle Assessment Framework}

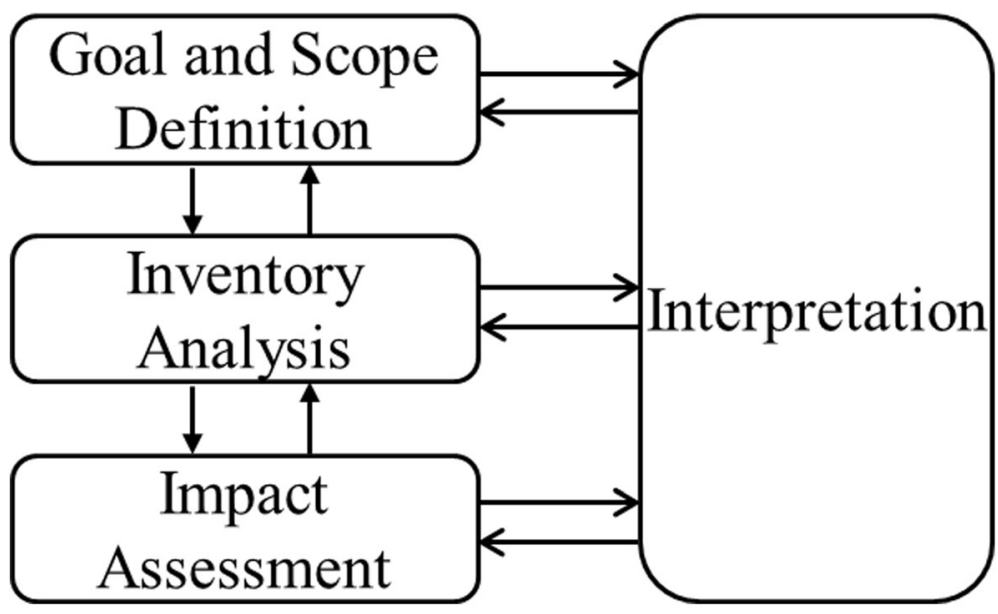

Fig. 1 Life cycle assessment stages according to ISO 14040 and ISO 14044 


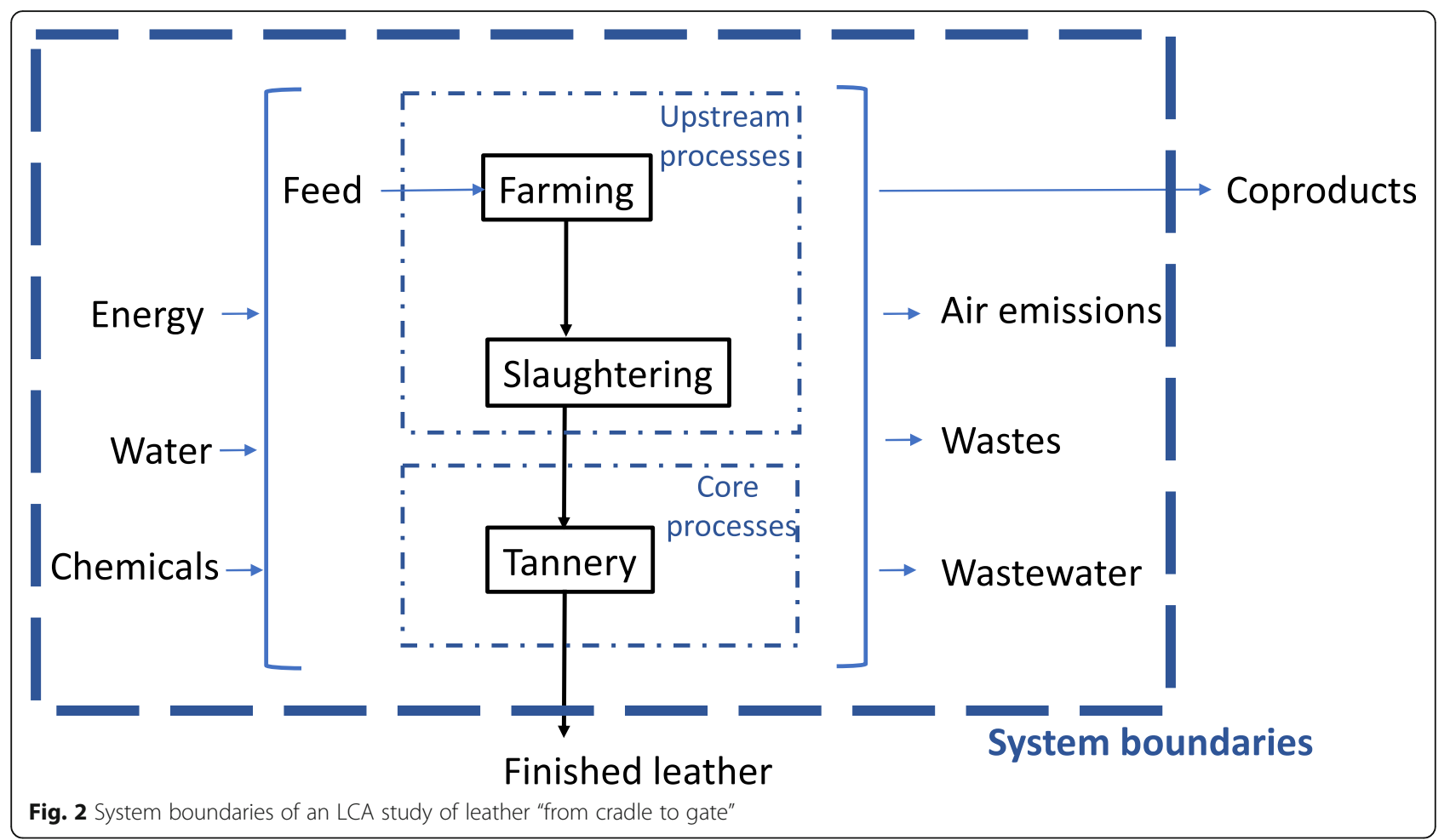

the functional unit might be "production of one pair of size EUR 42 shoes for men".

Inventory analysis phase consists in collecting process data (inputs and outputs from all the processes included in the system boundaries). These data are collected at laboratory or industrial scale and reviewed with mass balances. The processes are then modelled using specific LCA software (i.e., GaBi, Simapro, etc.) or in MS Excel sheets (if complexity is low). Inventory data and modelling is necessary for quantitative evaluation of impacts on the environment.

In the impact assessment phase, several impact categories can be evaluated: global warming, eutrophication, ozone depletion, smog, human toxicity, etc. It is important to choose the most appropriate and significant impact categories for each product. For leather, the impact categories suggested in the product environmental footprint (PEF) category rules [28] are: climate change (or global warming), ozone depletion, human toxicity-cancer, human toxicity-non cancer, particulate matter, ionisation radiation-human health, photochemical ozone formation-human health, acidification, eutrophication terrestrial, eutrophication fresh water, eutrophication marine, ecotoxicity freshwater, land and water use and abiotic resource depletion (minerals and fossil fuels).

When a study considers only life cycle green-house gas emissions, thus assessing global warming impact category, it is referred as carbon footprint (CF) and it has its own standard methodology. In case of assessing only life cycle water depletion, it is called water footprint (WF).

Finally, in the interpretation phase, the quantitative impact results obtained are discussed and preliminary questions are answered, i.e. which is the most impacting step in the life cycle of my product? What can I do to reduce global warming? Is the use of chromium significant in any impact category? Is energy consumption significant? etc.

\section{Methodology}

The sourcing process was performed by using the usual tools for scientific literature review. In the present case, Web of Science and Scopus were used to check all reported English literature related to Life Cycle Assessment (LCA) and leather. The key words used in the search were "(life cycle assessment or life cycle analysis or environmental footprint) \& leather" as the subject for the papers. Timespan was not limited. Only articles written in English language were collected; none of books, book chapters, reports, conferences were included.

Results obtained were organized in 4 items:

(1) LCA of the whole leather-production process. Only papers reporting LCA studies of a complete leatherproduction process are included. The environmental evaluation tool can be LCA or other life cycle 
related tools, such as carbon footprint (CF) or product environmental footprint (PEF).

(2) LCA of a step in the leather-production process. In this case, papers that study or compare the environmental performance (through LCA) of new technologies (i.e., enzymatic unhairing, chrome-free tanning, etc.) in leather processing are included.

(3) LCA of waste treatment or recycling. This item contains the literature related to the treatment process of waste coming from leather production (i.e., fleshings) or end-of-life waste from leather products (i.e., leather shoes).

(4) Life cycle thinking of leather production. It contains other types of papers which refer to LCA and have something to do with leather production (i.e., methodology development using a case-study on leather related processes or products, etc.).

\section{Results and discussion}

Leather related organizations and research centers have been investigating to find more efficient technologies and better environmental processes (i.e., preventing sulphide use in unhairing $[29,30]$ or chromium in tanning) since long ago. The aim of the present paper is not to collect all the existing literature related to process environmental-improvement research, but to collect the English literature where those improvements are measured through life cycle assessment (LCA) or life cycle thinking. Although several important reports, books or book chapters of this topic may exist, they are not included in this review.

\subsection{Results}

A total of 39 papers were found in the scientific literature related to this subject and they are summarized in Tables 1, 2, 3 and 4, classified within the four items described before (LCA of complete leather production process, LCA of a specific step, LCA of waste treatment and life cycle thinking papers). In addition, the tables show specific details from each paper, such as the year of publication, location of the study, inclusion or not of inventory data, etc.

\subsubsection{LCA of the whole leather production process}

In Table 1 (LCA of complete tannery processes), papers are classified in 4 different types (leather production, shoe manufacturing, leather clusters and new leather processing proposal) and organized by year within each type (from oldest to newest). There are 10 papers studying the whole leather-production process, 5 of them showing detailed inventory data from companies in different countries: Bangladesh, Chile, India, Italy, Spain and Turkey. There are also 3 papers related to shoe manufacturing, one of them (by Milà et al., 1998) showing inventory data of the involved processes and including impacts from leather production. The remaining two LCA related studies present environmental impact results (but not data on consumptions and emissions), one is about an industrial cluster in Italy and the other is about a new pilot-scale process to obtain leather from dehydration of delimed hides in Spain.

Although all the studies listed in Table 1 obtain the environmental impact of the whole leather production processes, they have different system boundaries (Fig. 2), meaning that the processes included in the study may differ. Only two of them [31, 41] include farming, slaughterhouse and leather production; three of them include slaughtering and leather production [33, 38, 39] and the rest include only leather production (core process, according to Fig. 2).

Results from Notarnicola et al. [33] are presented in Fig. 3, as an example of outputs from a leather LCA study. In this case, slaughterhouse, storage and tannery steps were included. Treatments of the wastewater and solid waste, from the tannery, were also assessed and visualized separately from tannery operations. In addition, chromium recovery from exhausted tanning-baths was considered, which led to an impact reduction. Impact categories evaluated in this study are shown in Fig. 3.

Impact categories: primary energy consumption (EC), abiotic resource depletion potential (ADP), global warming potential (GWP), acidification potential (AP), photochemical oxidant creation potential (POCP), human toxicity potential (HTP), fresh aquatic eco-toxicity potential (FAETP), terrestrial eco-toxicity potential (TETP) and nitrification potential (NP).

On another study, Rivela et al. [32] relate environmental impact with economic costs, showing that often a decrease of environmental impact can be achieved by reducing economic costs in a tannery in Chile (see Fig. 4). In this LCA study, only tannery operations are included and all assessed impact categories are weighted to obtain one single environmental index.

\subsubsection{LCA of a step in leather production process}

In Table 2 (LCA of a specific step in leather production), most of the papers refer to the steps in leather production with higher environmental problems: the unhairing (which uses sodium sulphide) and the tanning (using chromium salts). Two of the LCA-papers compare different unhairing processes (see some of the results in Fig. 5) and three compare chrome-tanning with other tanning agents. Other references are related to fatliquoring agents, degreasing and dyes. Most of the references in Table 2 present inventory data (inputs and outputs) for the processes they compare.

Results from Puccini et al. [48] (see Fig. 5) show that oxidative unhairing has lower ozone depletion and 
Table 1 LCA studies which include the complete leather production process

\begin{tabular}{|c|c|c|c|c|c|}
\hline \multicolumn{6}{|c|}{ LCA of whole leather production process } \\
\hline Type of study & Year & Location & $\begin{array}{l}\text { Inventory } \\
\text { data }\end{array}$ & Observations & Ref. \\
\hline LCA for ecolabel of leather & 2002 & Catalonia (Spain) & No & Quantified results for several impacts & {$[31]$} \\
\hline $\begin{array}{l}\text { LCA of leather industry in } \\
\text { developing countries }\end{array}$ & 2004 & Chile & Yes, full & $\begin{array}{l}\text { Inventory data aggregated for beamhouse, tanyard, retanning \& } \\
\text { dyeing and wastewater treatment }\end{array}$ & {$[32]$} \\
\hline Material flows in LCA of leather & 2009 & India & Yes, full & Materials inputs and outputs & [3] \\
\hline $\begin{array}{l}\text { Italian and Spanish leather } \\
\text { production systems }\end{array}$ & 2011 & Italy \& Spain & Yes, full & Inventory and LCA impacts of slaughterhouse and tanneries & {$[33]$} \\
\hline Leather finishing: aniline & 2014 & Taiwan & No & $\begin{array}{l}\mathrm{CF}^{\mathrm{a}} \text { of } 1 \mathrm{~m} 2 \text { finished aniline leather of various thicknesses: } 1.5 \\
\mathrm{~mm} ; 1.7 \mathrm{~mm} ; 1.9 \mathrm{~mm} \text { and all thicknesses }\end{array}$ & [34] \\
\hline $\begin{array}{l}\mathrm{CF}^{\mathrm{a}} \text { of a tanning company in } \\
\text { Turkey }\end{array}$ & 2015 & Turkey & Yes, full & Impact results on Climate Change & {$[35]$} \\
\hline $\begin{array}{l}\text { Multicriteria cost-benefit assess- } \\
\text { ment of tannery production }\end{array}$ & 2015 & Brazil & Some $e^{b}$ & $\begin{array}{l}\text { Optimization of water and chemicals use and recycling in } \\
\text { tanneries. Complements LCA with "emergy" accounting. }\end{array}$ & [36] \\
\hline $\begin{array}{l}\text { Vegetable vs chromium tanned } \\
\text { leather }\end{array}$ & 2017 & 7 countries & No & $\begin{array}{l}\text { Impacts of whole tanning process from } 12 \text { tanneries in } 7 \\
\text { countries. Vegetable and chrome tanning. }\end{array}$ & {$[37]$} \\
\hline $\begin{array}{l}\text { LCA of leather processing in } \\
\text { Bangladesh }\end{array}$ & 2018 & $\begin{array}{l}\text { Bangladesh and } \\
\text { India }\end{array}$ & Yes, full & $\begin{array}{l}\text { Environmental burden of two leather products: full-chrome lea- } \\
\text { ther and chrome-retanned crust leather from salted rawhides }\end{array}$ & {$[38,39]$} \\
\hline $\mathrm{CF}^{\mathrm{a}}$ of bovine upper leather & 2019 & $\begin{array}{l}\text { Chile, China, India, } \\
\text { Italy, and Spain }\end{array}$ & $\mathrm{Few}^{\mathrm{c}}$ & Carbon footprint was calculated as the environmental indicator & [40] \\
\hline LCA of footwear & 1998 & Spain & $\begin{array}{l}\text { Shoe } \\
\text { manufact. }\end{array}$ & $\begin{array}{l}\text { CML impact categories. Including impacts from leather } \\
\text { production }\end{array}$ & [41] \\
\hline Sustainable design of footwear & 2011 & Spain & $\begin{array}{l}\text { Shoe } \\
\text { manufact. }\end{array}$ & Synthetic shoes obtained smaller impact than leather shoes. & [42] \\
\hline LCA of footwear & 2019 & China & $\begin{array}{l}\text { Shoe } \\
\text { manufact. }\end{array}$ & Ecoindicator 99 & [43] \\
\hline $\begin{array}{l}\text { LCA of industrial cluster: } \\
\text { tanning cluster in Tuscany }\end{array}$ & 2017 & Tuscany (Italy) & No & Impact results from different collective-approach scenarios & [44] \\
\hline \multirow{2}{*}{$\begin{array}{l}\text { New continuous system to } \\
\text { produce leather }\end{array}$} & 2014 & Spain & Some $^{d}$ & Dehydrated leather and its & {$[45] \mathrm{CF}^{\mathrm{a}}$} \\
\hline & 2017 & Spain & Some & Subsequent tanning (at pilot plant scale) & $\begin{array}{l}\text { [46] more } \\
\text { impacts }\end{array}$ \\
\hline
\end{tabular}

${ }^{\mathrm{a} C F}$ carbon footprint

bInventory data only from unhairing-liming, pickling-tanning and wastewater treatment

'Only some data on leather finishing and wastewater treatment

${ }^{\mathrm{d} O n l y}$ total amounts required (of water, aggregated chemicals, electricity and thermal energy) compared with traditional leather production

toxicity (measured as ecotoxicity and human toxicity water) than traditional unhairing, but has higher impact in other categories such as global warming, soil toxicity or non-renewable resource depletion, among others. This is a clear example in which LCA shows that the reduction of one impact category (ie., toxicity in the water) entails increasing others (ie., global warming, soil toxicity and resource depletion).

\subsubsection{LCA of waste treatment or recycling}

Table 3 shows literature related to environmental assessment of products obtained from leather waste (4 papers). Two papers relate to the production of protein hydrolysate and biodiesel from leather waste (see Fig. 6), while the other two are more general and relate to circular economy and the recycling of leather waste. According to Pringle et al. [58] it is crucial to upgrade leather disposal methods from current incineration efforts (where the only resource recovered is a small fraction of the energy embedded in the waste) to material recycling, in order to enable a better return from resources invested. As an example of waste recycling, a study from Kiliç et al. [57] (Fig. 6), shows that biodiesel obtained from fleshings (BDF) has lower environmental impact (measured as global warming potential) than diesel obtained from fossil-fuels.

\subsubsection{Life cycle thinking of leather production}

Finally, in Table 4, 8 references are presented with a variety of ideas related to life cycle thinking and a global systemic approach. Daddi et al. [60] refer to the challenges companies should overcome when a better environmental performance (i.e. using recycled raw materials) leads to lower quality of product. They study how 
Table $\mathbf{2}$ LCA papers found in the literature, studying a specific part of the leather production

\begin{tabular}{|c|c|c|c|c|c|}
\hline \multicolumn{6}{|c|}{ LCA of a specific step in leather production } \\
\hline Type of study & year & location & Inventory data & Observations & Ref. \\
\hline $\begin{array}{l}\text { Dehairing: chemical vs } \\
\text { enzimatic }\end{array}$ & 2019 & $\begin{array}{l}\text { Catalonia } \\
\text { (Spain) }\end{array}$ & Some & $\begin{array}{l}\text { Chemical dehairing with landfilling or composting of the hair vs } \\
\text { enzymatic dehairing with composting }\end{array}$ & [47] \\
\hline LCA of hide oxidative unhairing & 2014 & Italy & Yes-unhairing & Oxidative $\left(\mathrm{H}_{2} \mathrm{O}_{2}\right)$ vs traditional unhairing & [48] \\
\hline $\begin{array}{l}\text { LCA of wet-white (chrome-free) } \\
\text { leather manufacture }\end{array}$ & 2016 & China & Yes-tanning & $\begin{array}{l}\text { Wet-white tanning (vegetable tannin with laponite nanoclay) vs } \\
\text { chrome tanning. }\end{array}$ & [49] \\
\hline $\mathrm{CF}^{\mathrm{a}}$ of chrome-free tanning & 2015 & China & Yes-tanning & $\begin{array}{l}\text { Several impact categories are evaluated: global warming, energy } \\
\text { consumption and human and marine toxicity }\end{array}$ & [50] \\
\hline $\begin{array}{l}\text { Development of a green } \\
\text { tanning process supported by } \\
\text { LCA }\end{array}$ & 2014 & Italy & Few & Comparing glucose tanning with conventional chrome-tanning. & [51] \\
\hline $\begin{array}{l}\text { LCA of new degreasing } \\
\text { formulation }\end{array}$ & 2017 & Italy & $\begin{array}{l}\text { Yes-lactose derivative } \\
\text { production in the lab }\end{array}$ & $\begin{array}{l}\text { Single-score LCA evaluation of the production of a new } \\
\text { degreasing agent (lactose derivative) to avoid ethoxylated } \\
\text { alcohols. }\end{array}$ & [52] \\
\hline $\begin{array}{l}\text { LCA of retanning, fatliquoring } \\
\text { and dyeing }\end{array}$ & 2019 & Italy & $\begin{array}{l}\text { Yes-retanning, } \\
\text { fatliquoring and } \\
\text { dyeing }\end{array}$ & $\begin{array}{l}\text { Sulphochlorinated paraffin and epoxidazed vegetable oil are } \\
\text { evaluated as alternative to fatliquoring agents }\end{array}$ & [53] \\
\hline LCA of leather dyestuff & 1998 & Switzerland & No & $\begin{array}{l}\text { Environmental risks of colorants depending on their toxicity and } \\
\text { portion entering the environment }\end{array}$ & [54] \\
\hline $\begin{array}{l}\text { LCA of acrylic acid (raw } \\
\text { material of leather process) }\end{array}$ & 2016 & Romania & $\begin{array}{l}\text { Yes-acrylic acid } \\
\text { production }\end{array}$ & $\begin{array}{l}\text { Production of acrylic acid from propylene was simulated using } \\
\text { commercial software and evaluated through LCA }\end{array}$ & [55] \\
\hline
\end{tabular}

${ }^{\mathrm{a} C F}$ carbon footprint

different companies solve the paradox. For example, a paper company, that produces tissue paper from recycled raw material, invested money to assure the quality of their product in the three key characteristics (tenderness, resistance, and capacity of liquid absorption) in order to match the product quality of their competitors, who use virgin raw material. Another paper mill made the investment to ensure a high quality of the recycled paper they receive as raw material.

A paper by Gonzalez-Quijano [61] discusses the future of leather industries as a consequence of emerging society values. The industry has to reassure consumers and reach greater levels of transparency in its supply chain. One of the proposed actions in the paper is the use of LCA. It presents the category rules to perform an LCA of leather (PEFCR) recently developed in Europe. All stakeholders in the value chain (leather organizations, red-meat and milk producers, etc.) were included to develop these rules. Another paper, by Gül et al. [62], discusses the category rules to perform an LCA about non-leather shoes (i.e. sport-shoes) and stresses the difficulties to find a benchmark which the results should be compared with.

On the other hand, Moktadir et al. [63] proposed a model to identify the barriers to implementing reverse logistic (which is needed to collecting, reusing/recycling and landfilling post-consumer waste). The model was applied to leather-shoes in Bangladesh. The major barrier categories identified are technology \& infrastructure, knowledge \& support, organizational policy, financial constraints and operational issues. Knowledge \& support (lack of interest and support from top management) and

Table $\mathbf{3}$ LCA papers studying leather-waste treatment processes

\begin{tabular}{|c|c|c|c|c|c|}
\hline \multicolumn{6}{|l|}{ LCA of waste treatment } \\
\hline Type of study & Year & Location & $\begin{array}{l}\text { Inventory } \\
\text { data }\end{array}$ & Observations & Ref. \\
\hline $\begin{array}{l}\text { Protein hydrolysate } \\
\text { production }\end{array}$ & 2017 & Germany & Yes & $\begin{array}{l}\text { Protein hydrolysates used as plant biostimulants are evaluated comparing } \\
\text { hydrolysates animal-derived (leather waste, chemical hydrolysis) and legume-derived } \\
\text { (enzymatic hydrolysis). }\end{array}$ & {$[56]$} \\
\hline $\begin{array}{l}\mathrm{CF}^{\mathrm{a}} \text { of biodiesel from } \\
\text { fleshings }\end{array}$ & 2014 & Spain & Yes & Production of biodiesel from fleshings is evaluated & [57] \\
\hline $\begin{array}{l}\text { Circular economy within } \\
\text { leather recycling }\end{array}$ & 2016 & UK & No & $\begin{array}{l}\text { Landfilling and incineration of leather products result in environmental and } \\
\text { economic losses. Challenges in leather recycling are discussed. }\end{array}$ & [58] \\
\hline $\begin{array}{l}\text { Waste recovery in leather } \\
\text { industrial cluster }\end{array}$ & 2008 & $\begin{array}{l}\text { Catalonia } \\
\text { (Spain) }\end{array}$ & Few & State-of-the-art of leather tanning waste in Catalonia & [59] \\
\hline
\end{tabular}

${ }^{\mathrm{a} C F}$ : carbon footprint 
Table 4 Life cycle thinking papers related to leather production Life cycle thinking of leather production

\begin{tabular}{lllll}
\hline Type of study & Year & Location & $\begin{array}{l}\text { Inventory } \\
\text { data }\end{array}$ & Observations \\
\hline Paradoxes of circular economy: & 2019 Italy & No & Circular economy challenges may lead to paradoxical tensions for
\end{tabular}

Circular economy challenges may lead to paradoxical tensions for
companies: use of recycled materials may result in lower quality of product. Companies from leather, paper and textile sectors were interviewed

2019 Europe $\quad$ No future for leather $\quad \begin{aligned} & \text { Leather PEF category rules at EU is explained and environmental } \\ & \text { challenges and opportunities for leather companies are discussed. }\end{aligned}$
for non-leather shoes

Defining the category rules for an LCA of sport-shoes. Difficulty to define the benchmark and influence of the lifetime in the impacts of the shoes.

Barriers to reverse logistic of

2019 Bangladesh No leather shoes

Framework to measure

2019 Italy No

sustainability in firms: textile \&

leather

Water footprint (WF)

methodology: leather

Eco-design of luxury personal accessories

Influence of leather ecological properties on its products ecodesign
2018 Guanajuato No (Mexico)

2017 Italy No

2014 China

Main barriers to implement reverse logistics (RL) in Bangladesh are identified. This is crucial for leather footwear reuse and recycle.

Framework to organize sustainable practices relevant to manufacturing firms (leather or textile).

Some

Methodology for calculating the WF of an industrial product related to the context. The case of chrome-tanned leather in Guanajuato.

When Fashion brands combine eco-design and recycling of stored (outmoded) materials and products.

financial constraints (high initial and operating costs and uncertainty of economic return) were often found to be important.

Other described topics in the literature (Table 4) are: ecodesign to recycle outmoded leather products (see Fig. 7), the importance of the leather supply in eco-design of leather products (not all the leather has the same environmental profile), a framework to measure sustainability (see Fig. 8) and water footprint of tanning processes in Mexico.
According to Cimatti et al. [66], fashion industry is considered unsustainable due to the rapidity with which a product becomes outdated. Some sustainable methods and techniques, such as eco-design and recycling, can well fit fashion manufacturing companies and LCA can help designers define the characteristics of the product [66]. An example of this is the Italian fashion company Borbonese, which manufactures new original products using stored waste (see Fig. 7). According to their

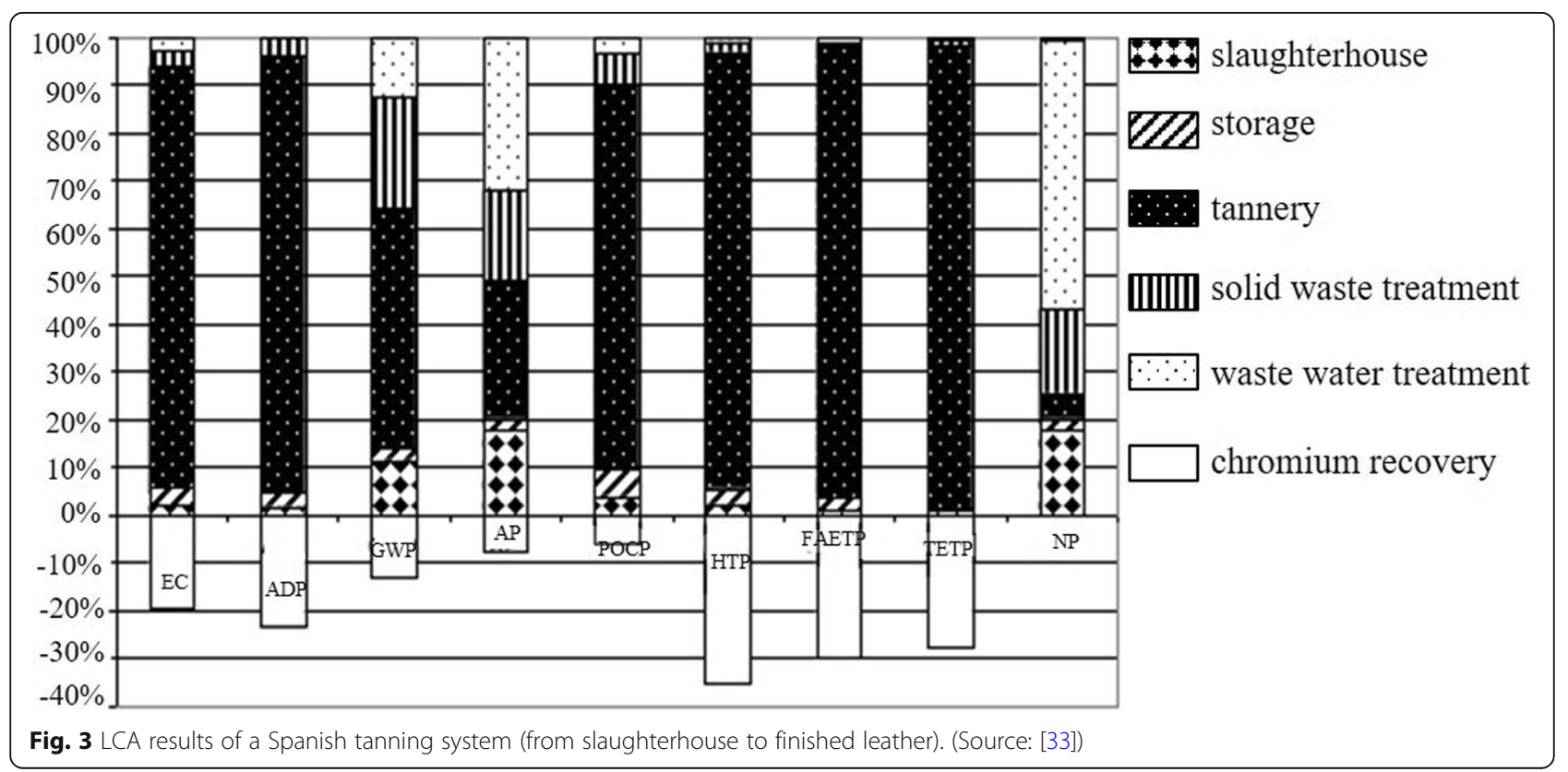


Action D: action B2 and primary and secondary treatments.

Action C: action B2 and primary treatment.

Action B2: action B1 and auditing lime and $\left(\mathrm{NH}_{4}\right)_{2} \mathrm{SO}_{4}$ addition.

Action B1: high exhaustion chrome-tanning process.

Action A2: action A1 and auditing lime and $\left(\mathrm{NH}_{4}\right)_{2} \mathrm{SO}_{4}$ addition.

Action A1: improved operational conditions of the chrome-tanning process.

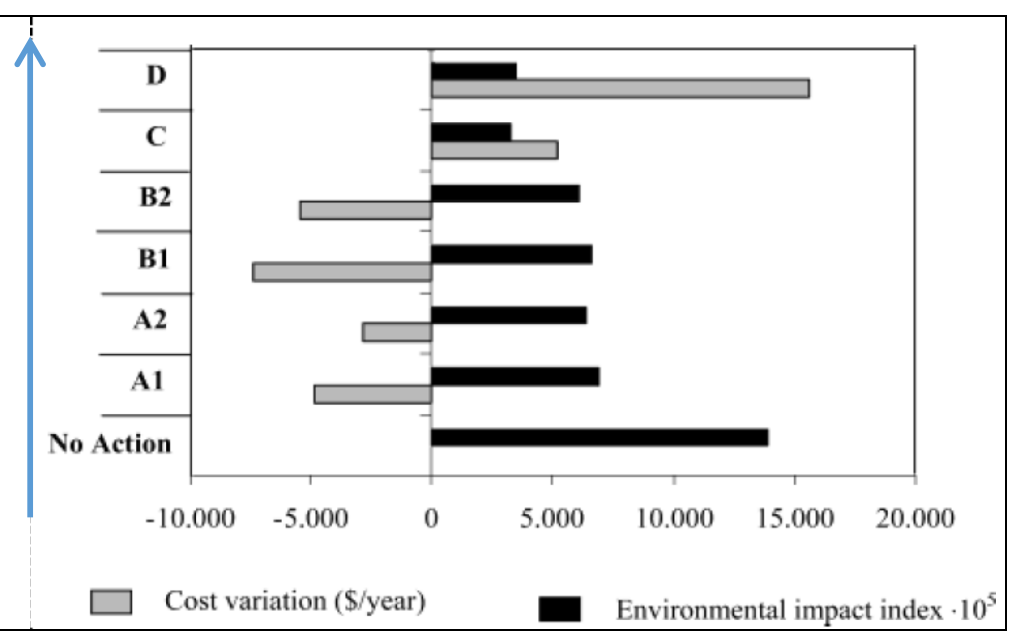

Fig. 4 Environmental and cost indexes of different actions. (Source: [32])

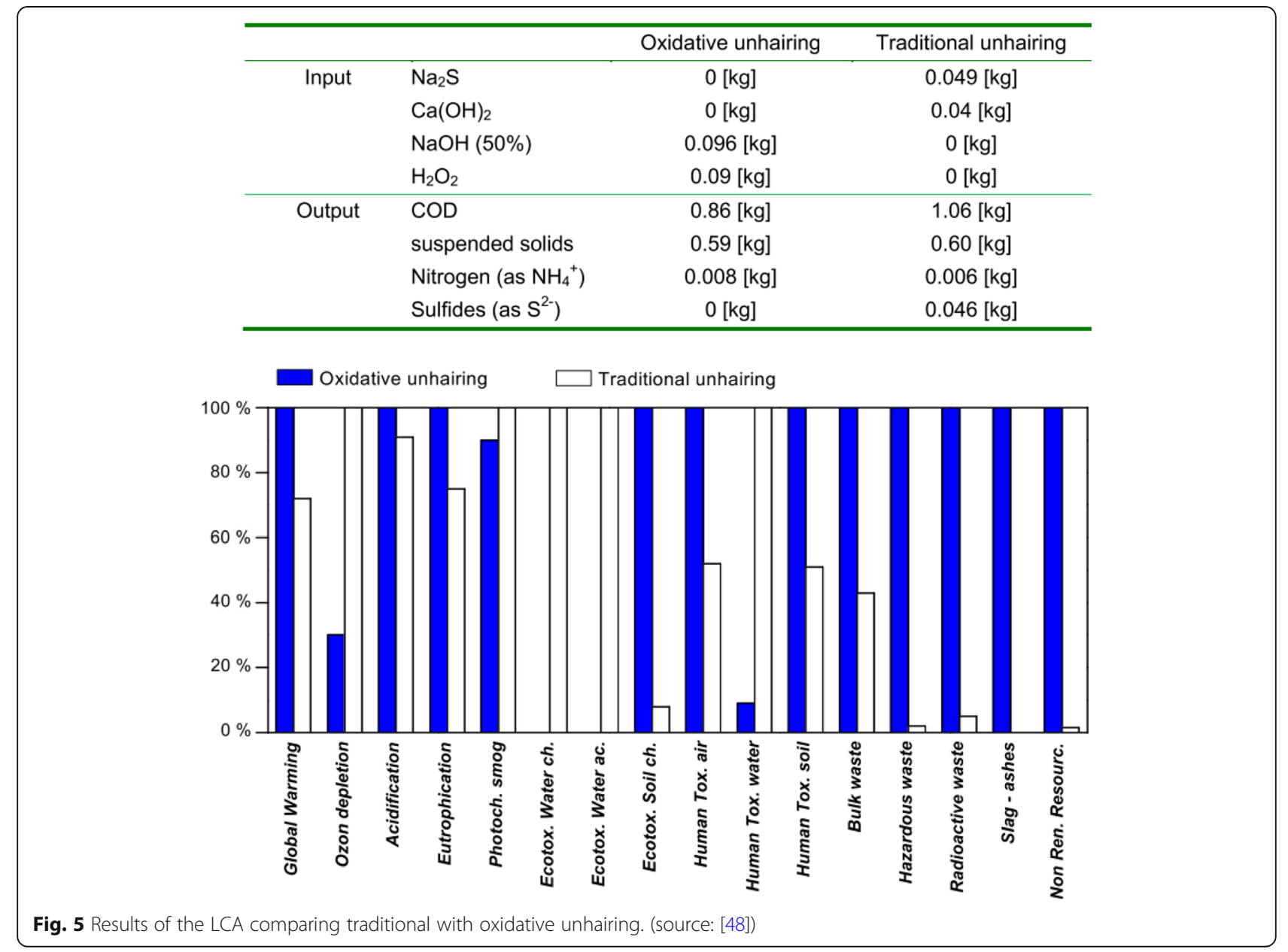




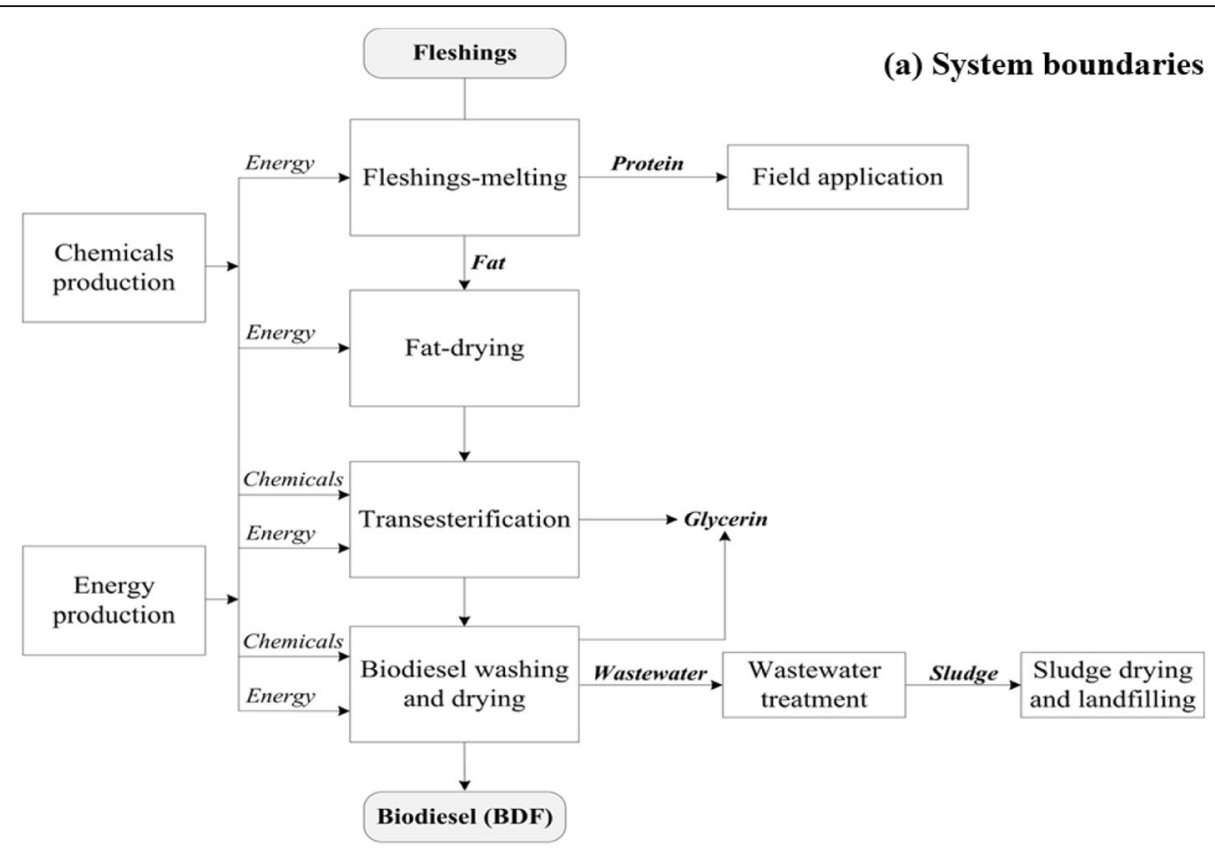

(b) GWP $\left[\mathrm{kg} \mathrm{CO} \mathrm{CO}_{2} \mathrm{eq}\right.$

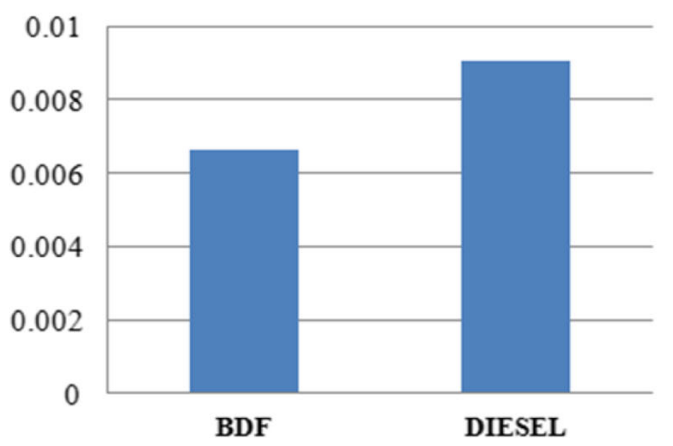

Fig. 6 LCA of the biodiesel produced from fleshings (BDF): (a) system boundaries, and (b) global warming potential (GWP) results compared with diesel. (Source: [57]) Copyright 2014. Reproduced with permission from Journal of American Leather Chemists Association

experience, the strongest environmental footprint corresponds to transport and leather treatments.

In the context of sustainability assessment, according to Pande and Kumar-Adil [64], value chain can be seen as a promising framework as it offers an activity based view of a firm, by systematically segregating all activities into primary and support activities (Fig. 8). Notice that in the "Support Activity Domain", sustainable design, sourcing (suppliers) and employee or community development are important activities. A firm should address to achieve sustainability. Thus, not only its own production, transports and sales are important issues, but also other activities in the value chain (as shown in Fig. 8).

Therefore, by seeing what is published in the literature so far, leather production should be in close relation with LCA and life cycle thinking to address sustainability issues. Future perspectives for leather industries line up to widen the view from the leather production itself into considering all processes along the value chain, not only for economic reasons but also for environmental ones.

\subsection{Discussion}

The outputs from the literature review can also be classified under two main types: LCA papers and life cycle thinking papers.

(1) LCA papers: presenting input/output data of processes and evaluating their environmental impacts.

(2) Life cycle thinking papers: discussing the implications of life cycle thinking to the future of leather industry. 

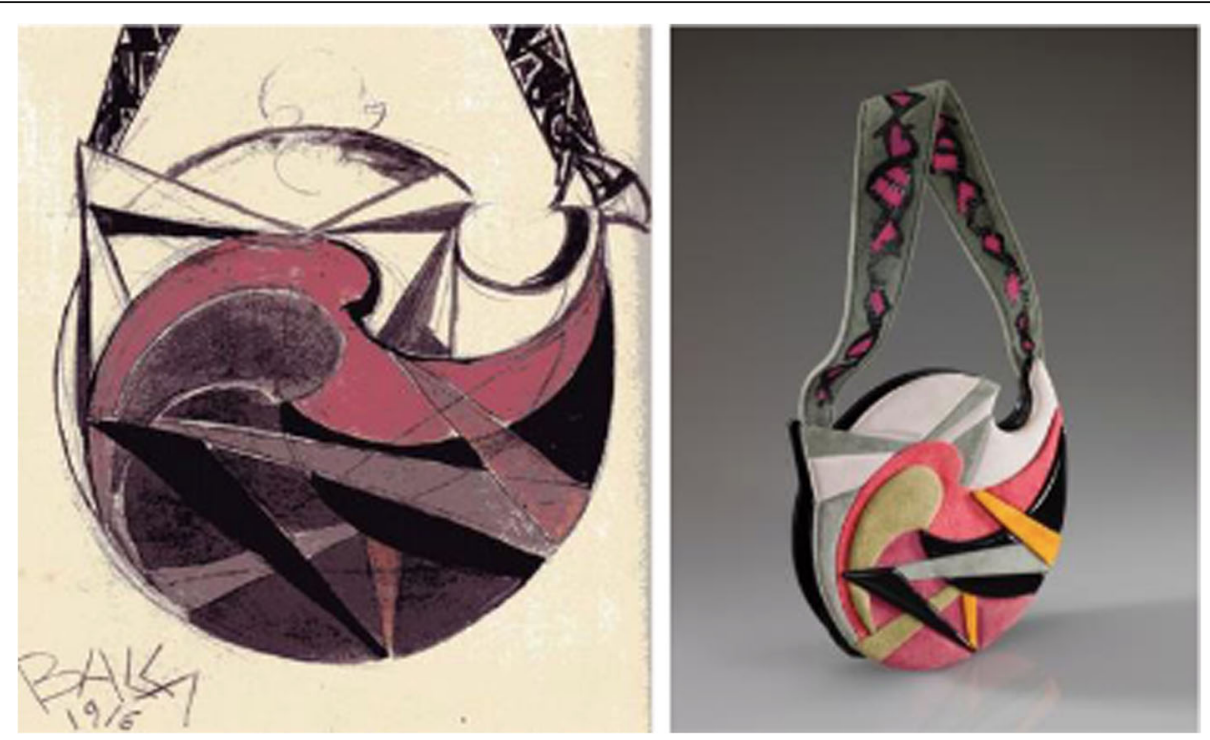

Fig. 7 Handbag manufactured by Borbonese using stored waste (Source: [66]). Copyright 2017. Reproduced with permission from Elsevier Ltd.

\begin{tabular}{|c|c|c|c|c|c|c|}
\hline \multirow{6}{*}{ 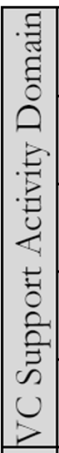 } & \multicolumn{6}{|c|}{$\begin{array}{c}\text { 1.Sustainable Design } \\
{[\text { Product Design, Process Design] }}\end{array}$} \\
\hline & \multirow{2}{*}{\multicolumn{6}{|c|}{$\begin{array}{c}\text { 2.Sustainable Sourcing } \\
\text { [Supplier Selection, Procurement, Supplier Development] }\end{array}$}} \\
\hline & & & & & & \\
\hline & \multicolumn{6}{|c|}{$\begin{array}{c}\text { 3.Sustainability Standards \& Systems } \\
\text { [ Sustainability Assessment, Sustainability Reporting] }\end{array}$} \\
\hline & \multicolumn{6}{|c|}{$\begin{array}{l}\text { 4.Employee Development } \\
\text { [Employee Training, Employee Care \& Welfare] }\end{array}$} \\
\hline & \multicolumn{6}{|c|}{$\begin{array}{c}\text { 5.Community Development } \\
\text { [Employment Generation, CSR Activities] }\end{array}$} \\
\hline 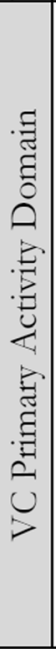 & $\begin{array}{l}\text { 1.Sustainable } \\
\text { In-Bound } \\
\text { Logistics } \\
\text { [Inspection, } \\
\text { Transportation, } \\
\text { Warehouse } \\
\text { \&Inventory } \\
\text { Management] }\end{array}$ & $\begin{array}{c}\text { 2.Sustainable } \\
\text { Manufacturing } \\
\text { Operations } \\
\text { [Waste } \\
\text { Management, } \\
\text { Energy } \\
\text { Conservation, } \\
\text { Pollution } \\
\text { Prevention, } \\
\text { Water } \\
\text { Conservation, } \\
\text { Agile } \\
\text { Manufacturing, } \\
\text { Worker's Health } \\
\text { \& Safety] }\end{array}$ & $\begin{array}{l}\text { 3.Sustainable } \\
\text { Out-Bound Logistics } \\
\text { [Out-bound Testing } \\
\text { \& Inspection, } \\
\text { Sustainable } \\
\text { Packaging, } \\
\text { Warehouse \& } \\
\text { Inventory } \\
\text { Management, } \\
\text { Transportation] }\end{array}$ & $\begin{array}{l}\text { 4. Sustainable } \\
\text { Marketing } \\
\text { \&Sales } \\
\text { Product } \\
\text { Promotion, } \\
\text { Product Sales] }\end{array}$ & $\begin{array}{c}\text { 5.Sustainable } \\
\text { After Sales Service } \\
\text { [Spare Parts } \\
\text { Management, } \\
\text { Customer } \\
\text { Complaints } \\
\text { Management, } \\
\text { Repair \& } \\
\text { Maintenance] }\end{array}$ & $\begin{array}{c}\text { 6. Reverse } \\
\text { Logistics } \\
\text { Product } \\
\text { Return, } \\
\text { Post } \\
\text { Return] }\end{array}$ \\
\hline
\end{tabular}

Fig. 8 Framework to evaluate sustainable value chain (VC) practices. (Source: [64]) 
LCA papers are useful to identify the environmental hotspots in the life cycle of leather and serve as a diagnosis for further improvement of its different steps. These papers are mostly presented in Tables 1, 2 and 3 . Some of them also highlight synergies and benefits of leather companies working in clusters [60].

Life cycle thinking papers are important in longerterm strategies for leather industries, and to foresee customers' preferences according to new consumption patterns. Most of the papers are presented in Table 4, although there is one in Table 3 (related to circular economy of leather recycling [58]) and three more in Table 1 (related to shoe manufacturing).

These papers address environmental trends and identify some of the gaps leather life-cycle has nowadays. An example is the end-of-life of leather and leather goods, which is mainly landfilling or incineration [58] with scarce recovery of the resources invested. This links to the paper which identifies the barriers to reverse logistics for a better collection and recyclability of leather goods [63] and to the eco-design of leather products $[66,67]$, where end-of-life is of great concern. Our suggestion to strengthen the sustainability of leather production is to address, as soon as possible, the recyclability of leather at its end-of-life. It is very important to make leather and leather goods recyclable to comply with sustainability and circular economy trends.

Actually, one of the main risks leather industry faces is the tendency of people becoming vegetarian (for various reasons) and the substitution of leather for other bio-waste vegetable materials [60], like pineapple or banana fibers to make shoes. These risks can be reduced by making leather more sustainable (in the whole life cycle) and stressing its particular better properties for certain applications.

Leather industry should implement life cycle thinking as a strategy to become more sustainable and circular, adapting leather production to market requirements and new society trends.

\section{Conclusions}

The review of scientific literature about LCA and leather produced 39 papers published in peer-reviewed journals (all in English language). The high number of papers shows the importance of the subject. Most of the papers, 30 , were published during the last 6 years (2014 to 2019), which means that, for leather industries around the world, this subject is nowadays important. Society is changing, and production and consumption patterns will also change accordingly. Leather industry, which has been highly important since ancient history, needs to understand this change and continuously innovate to be competitive and sustainable. LCA can help leather industry have a wider view of environmental issues and guide leather innovation to sustainability.

\section{Abbreviations}

CF: Carbon footprint; EUR: Shoe size criteria in Europe; ISO: International organization for standardization; LCA: Life cycle assessment; PEF: Product environmental footprint; PEFCR: Product environmental footprint category rules; WF: Water footprint

\section{Acknowledgements}

The authors wish to thank the support by UNESCO to build scientific international network.

The authors are responsible for the choice and presentation of information contained in this paper as well as for the opinions expressed therein, which are not necessarily those of UNE and do not commit this Organization.

\section{Authors' contributions}

DN was a major contributor in literature searching, summarizing and organizing all related papers. JW checked and revised the references and Figures RP prepared the writing and interpretation of the results. And WL and PF revised the written manuscript. All authors read and approved the final manuscript.

\section{Funding}

This work was financially supported by different sources: a) D. Navarro was funded by the company Curtidos Badia; b) W. Lin by by the National Key Research and Development Program of China (2019YFC1904500), and National Natural Science Foundation (NNSF) of China (21978177); c) P. Fullana-i-Palmer and R. Puig by the Ceres-Procon Project (CTM2016-76176C2-2-R) (AEI/FEDER, UE), financed by the Spanish Ministry of Economy and Competitiveness.

\section{Availability of data and materials}

All data generated or analysed during this study are included in this published article.

\section{Competing interests}

The authors declare that they have no competing interests.

\section{Author details}

${ }^{1}$ Environmental Engineering doctoral program, Universitat Politècnica de Catalunya (UPC), C/ Jordi Girona 1-3, 08034 Barcelona, Spain. ${ }^{2}$ Curtidos Badia SAU, c/ Sol, 52, 08700 Igualada, Spain. ${ }^{3}$ Department of Biomass and Leather Engineering, Key Laboratory of Leather Chemistry and Engineering of Ministry of Education, Sichuan University, Chengdu 610065, China. ${ }^{4}$ UNESCO Chair in Life Cycle and Climate Change ESCI-UPF, Pompeu Fabra University, Pg. Pujades 1, 08003 Barcelona, Spain. ${ }^{5}$ Department of Computer Science and Industrial Engineering, Universitat de Lleida (UdL), Pla de la Massa, 8, 08700 Igualada, Spain.

Received: 17 March 2020 Accepted: 6 August 2020

Published online: 09 November 2020

References

1. Saravanabhavan S, Thanikaivelan P, Rao JR, Nair BU, Ramasami T. Natural leathers from natural materials: progressing toward a new arena in leather processing. Environ Sci Technol. 2004;38:871-9. https://doi.org/10.1021/ es0345540.

2. Covington A. Quo vadit chromium? The future directions of tanning. J Am Leather Chem Assoc. 2008;103:7-23.

3. Joseph K, Nithya N. Material flows in the life cycle of leather. J Clean Prod. 2009;17:676-82. https://doi.org/10.1016/j.jclepro.2008.11.018.

4. Hu J, Xiao Z, Zhou R, Deng W, Wang M, Ma S. Ecological utilization of leather tannery waste with circular economy model. J Clean Prod. 2011;19: 221-8. https://doi.org/10.1016/j.jclepro.2010.09.018.

5. The Ellen MacArthur Foundation. Towards a circular economy - economic and business rationale for an accelerated transition. 2015.

6. Suárez-Eiroa B, Fernández E, Méndez-Martínez G, Soto-Oñate D. Operational principles of circular economy for sustainable development: linking theory and practice. J Clean Prod. 2019;214:952-61. https://doi.org/10.1016/j.jclepro. 2018.12.271

7. Simon B. What are the most significant aspects of supporting the circular economy in the plastic industry? Resour Conserv Recycl. 2019;141:299-300. https://doi.org/10.1016/j.resconrec.2018.10.044. 
8. Gaustad G, Krystofik M, Bustamante M, Badami K. Circular economy strategies for mitigating critical material supply issues. Resour Conserv Recycl. 2018;135:24-33. https://doi.org/10.1016/j.resconrec.2017.08.002

9. Laso J, García-Herrero I, Margallo M, Vázquez-Rowe I, Fullana P, Bala A, et al. Finding an economic and environmental balance in value chains based on circular economy thinking: an eco-efficiency methodology applied to the fish canning industry. Resour Conserv Recycl. 2018;133:428-37. https://doi. org/10.1016/j.resconrec.2018.02.004.

10. Principato L, Ruini L, Guidi M, Secondi L. Adopting the circular economy approach on food loss and waste: the case of Italian pasta production. Resour Conserv Recycl. 2019;144:82-9. https://doi.org/10.1016/j.resconrec. 2019.01.025.

11. Teigiserova DA, Hamelin L, Thomsen M. Review of high-value food waste and food residues biorefineries with focus on unavoidable wastes from processing. Resour Conserv Recycl. 2019;149:413-26. https://doi.org/10.1016/ j.resconrec.2019.05.003.

12. Delgado-Aguilar M, Pèlach M-A, Mutjé P, Fullana-i-Palmer P. Are cellulose Nanofibers a solution for a more circular economy of paper products? Environ Sci Technol. 2015;15:629-37. https://doi.org/10.1021/acs.est.5b02676.

13. Esteve-Turrillas FA, de la Guardia M. Environmental impact of recover cotton in textile industry. Resour Conserv Recycl. 2017;116:107-15. https://doi.org/ 10.1016/j.resconrec.2016.09.034

14. Yousef S, Tatariants M, Tichonovas M, Sarwar Z, Jonuškienè I, Kliucininkas L. A new strategy for using textile waste as a sustainable source of recovered cotton. Resour Conserv Recycl. 2019;145:359-69. https://doi.org/10.1016/j. resconrec.2019.02.031.

15. Navarro A, Puig R, Martí E, Bala A, Fullana-i-Palmer P. Tackling the relevance of packaging in life cycle assessment of virgin olive oil and the environmental consequences of regulation. Environ Manag. 2018;62:277-94. https://doi.org/10.1007/s00267-018-1021-x.

16. Civancik-Uslu D, Puig R, Ferrer L, Fullana-i-Palmer P. Influence of end-of-life allocation, credits and other methodological issues in LCA of compounds: an in-company circular economy case study on packaging. J Clean Prod. 2019;212:925-40. https://doi.org/10.1016/j.jclepro.2018.12.076.

17. ISO 14044. Environmental Management - Life Cycle Assessment Requirements and Guidelines. Geneva: International Organization for Standardization; 2006.

18. Muñoz I, Gazulla C, Bala A, Puig R, Fullana P. LCA and ecodesign in the toy industry: case study of a teddy bear incorporating electric and electronic components. Int J Life Cycle Assess. 2009;14:64-72. https://doi.org/10.1007/ s11367-008-0044-6

19. Civancik-uslu D, Puig R, Voigt S, Walter D, Fullana-i-palmer P. Improving the production chain with LCA and eco-design : application to cosmetic packaging. Resour Conserv Recycl. 2019;151:104475. https:/doi.org/10.1016/ j.resconrec.2019.104475.

20. Bala A, Laso J, Abejón R, Margallo M, Fullana-i-Palmer P, Aldaco R. Environmental assessment of the food packaging waste management system in Spain: understanding the present to improve the future. Sci Total Environ. 2020;702:134603. https://doi.org/10.1016/.scitotenv.2019.134603.

21. Abejón R, Laso J, Margallo M, Aldaco R, Blanca-Alcubilla G, Bala A, et al. Environmental impact assessment of the implementation of a depositrefund system for packaging waste in Spain: a solution or an additional problem? Sci Total Environ. 2020;721:137744. https://doi.org/10.1016/j. scitotenv.2020.137744

22. Blanca-Alcubilla G, Bala A, De-Castro N, Colomé R, Fullana-i-Palmer P. Is the reusable tableware the best option? Analysis for the aviation catering sector with a Life Cycle Approach. Sci Total Environ. 2019;708:135121. https://doi. org/10.1016/j.scitotenv.2019.135121.

23. Abejón R, Bala A, Vazquez-Rowe I, Aldaco R, Fullana i Palmer P. When plastic packaging should be preferred: life cycle analysis of packages for fruit and vegetable distribution in the Spanish peninsular market. Resour Conserv Recycl. 2020;155:104666. https://doi.org/10.1016/j.resconrec.2019.104666.

24. Batlle-Bayer L, Aldaco R, Bala A, Fullana-i-Palmer P. Toward sustainable dietary patterns under a water-energy-food nexus life cycle thinking approach. Curr Opin Environ Sci Heal. 2020;13:61-7. https://doi.org/10.1016/ j.coesh.2019.11.001.

25. Ros T, Celades I, Masoni P, Vilalta L, Fullana-I-Palmer P, Monfort E. Environmental comparison of indoor floor coverings. Sci Total Environ. 2019;693:133519. https://doi.org/10.1016/j.scitotenv.2019.07.325.

26. Fullana i Palmer P, Puig R, Bala A, Baquero G, Riba J, Raugei M. From life cycle assessment to life cycle management: a case study on industrial waste management policy making. J Ind Ecol. 2011;15:458-75. https://doi.org/10. 1111/j.1530-9290.2011.00338.x.

27. ISO 14040. Environmental Management-Life Cycle Assessment - Principles and Framework. International Organization for Standardization, Geneva, Switzerland. ISO 14044 (2006) Environmental Management - Life Cycle Assessment - Requirements and Guidelines. Geneva: International Organization for Standardization; 2006.

28. De Rosa-Giglio P, Fontanella A, Gonzalez-Quijano G, loannidis I, Nucci B, Brugnoli F. Leather product environmental footprint category rules (leather PEF(R); 2018.

29. Nazer DW, Al-Sa'Ed RM, Siebel MA. Reducing the environmental impact of the unhairing-liming process in the leather tanning industry. J Clean Prod. 2006;14:65-74. https://doi.org/10.1016/j.jclepro.2005.04.002.

30. Morera JM, Bacardit A, Ollé L, Bartolí E, Borràs MD. Minimization of the environmental impact in the unhairing of bovine hides. Chemosphere. 2008;72:1681-6. https://doi.org/10.1016/j.chemosphere.2008.05.023.

31. Milà i Canals L, Domènech X, Rieradevall J, Puig R, Fullana P. Use of life cycle assessment in the procedure for the establishment of environmental criteria in the Catalan eco-label of leather. Int J Life Cycle Assess. 2002;7:3946. https://doi.org/10.1007/BF02978908.

32. Rivela B, Moreira MT, Bornhardt C, Méndez R, Feijoo G. Life cycle assessment as a tool for the environmental improvement of the tannery industry in developing countries. Environ Sci Technol. 2004;38:1901-9. https://doi.org/ 10.1021/es034316t.

33. Notarnicola B, Puig R, Raggi A, Fullana P, Tassielli G, De Camillis C, Rius A. Life cycle assessment of Italian and Spanish bovine leather production systems. Afinidad. 2011;68:167-80.

34. Chen KW, Lin LC, Lee WS. Analyzing the carbon footprint of the finished bovine leather: a case study of aniline leather. Energy Procedia. 2014;61: 1063-6. https://doi.org/10.1016/..egypro.2014.11.1023.

35. Killç E, Puig R, Zengin G, Zengin CA, Fullana-i-Palmer P. Corporate carbon footprint for country climate change mitigation: a case study of a tannery in Turkey. Sci Total Environ. 2018;635:60-9. https://doi.org/10.1016/j.scitotenv. 2018.04.111.

36. Giannetti BF, Agostinho F, Moraes LC, Almeida CMVB, Ulgiati S. Multicriteria cost-benefit assessment of tannery production: the need for breakthrough process alternatives beyond conventional technology optimization. Environ Impact Assess Rev. 2015;54:22-38. https://doi.org/10.1016/j.eiar.2015.04.006.

37. Laurenti R, Redwood M, Puig R, Frostell B. Measuring the environmental footprint of leather processing technologies. J Ind Ecol. 2017;21:1180-7. https://doi.org/10.1111/jiec.12504.

38. Chowdhury ZUM, Ahmed T, Antunes APM, Paul HL. Environmental life cycle assessment of leather processing industry: a case study of Bangladesh. J Soc Leather Technol Chem. 2018;102:18-26.

39. Chowdhury Z, Ahmed T, Hashem M. Materials and energy flow in the life cycle of leather: a case study of Bangladesh. Mater Tech. 2017;105:1-12. https://doi.org/10.1051/mattech/2018013.

40. Chen M, Duan Y, Dong L, Chen M, Cheng H. Country-level life cycle assessment of carbon footprint in processing of bovine upper leather. J Am Leather Chem Assoc. 2019;114:194-203.

41. Milà L, Domènech X, Rieradevall J, Fullana P, Puig R. Application of life cycle assessment to footwear. Int J Life Cycle Assess. 1998;3:203-8. https://doi. org/10.1007/BF02977570.

42. Herva M, Álvarez A, Roca E. Sustainable and safe design of footwear integrating ecological footprint and risk criteria. J Hazard Mater. 2011;192: 1876-81. https://doi.org/10.1016/j.jhazmat.2011.07.028.

43. Fan S, Ding S, Li R. Life cycle assessment of leather shoe manufacturing process based on Simapro. J Soc Leather Technol Chem. 2019;103:231-40.

44. Daddi T, Nucci B, Iraldo F. Using life cycle assessment (LCA) to measure the environmental benefits of industrial symbiosis in an industrial cluster of SMEs. J Clean Prod. 2017;147:157-64. https://doi.org/10.1016/j.jclepro.2017. 01.090 .

45. Bacardit A, Baquero G, Sorolla S, Ollé L. Evaluation of a new sustainable continuous system for processing bovine leather. J Clean Prod. 2015;101: 197-204. https://doi.org/10.1016/j.jclepro.2015.04.012.

46. Baquero G, Sorolla S, Ollé L, Bacardit A. Environmental assessment of dehydration processes for bovine leather. J Am Leather Chem Assoc. 2017; 112:102-8.

47. Catalán E, Komilis D, Sánchez A. A life cycle assessment on the Dehairing of rawhides: chemical treatment versus enzymatic recovery through solid state fermentation. J Ind Ecol. 2019;23:361-73. https://doi.org/10.1111/jiec.12753. 
48. Puccini M, Seggiani M, Castiello D, Vitolo S. DEPOXO process: technical and environmental study of hide oxidative unhairing. Chem Eng Trans. 2014;36: 193-8. https://doi.org/10.3303/CET1436033.

49. Shi J, Puig R, Sang J, Lin W. A comprehensive evaluation of physical and environmental performances for wet-white leather manufacture. J Clean Prod. 2016;139:1512-9. https://doi.org/10.1016/j.jclepro.2016.08.120.

50. Xu X, Baquero G, Puig R, Shi J, Sang J, Lin W. Carbon footprint and toxicity indicators of alternative chromium-free tanning in China. J Am Leather Chem Assoc. 2015;110:130-7.

51. Puccini M, Seggiani M, Castiello D, Vitolo S. Sustainability in process innovation: development of a green tanning process supported by LCA methodology. J Am Leather Chem Assoc. 2014;109:110-6.

52. Rosa R, Pini M, Neri P, Corsi M, Bianchini R, Bonanni M, et al. Environmenta sustainability assessment of a new degreasing formulation for the tanning cycle within leather manufacturing. Green Chem. 2017;19:4571-82. https:/ doi.org/10.1039/c7gc01900a.

53. Tasca AL, Puccini M. Leather tanning: life cycle assessment of retanning, fatliquoring and dyeing. J Clean Prod. 2019;226:720-9. https://doi.org/10. 1016/j.jclepro.2019.03.335.

54. Püntener AG. Risk assessment of leather dyestuffs. J Soc Leather Technol Chem. 1998;82:1-4.

55. Petrescu L, Fermeglia M, Cormos CC. Life cycle analysis applied to acrylic acid production process with different fuels for steam generation. J Clean Prod. 2016;133:294-303. https://doi.org/10.1016/j.jclepro.2016.05.088.

56. Colantoni A, Recchia L, Bernabei G, Cardarelli M, Rouphael Y, Colla G. Analyzing the environmental impact of chemically-produced protein hydrolysate from leather waste vs. enzymatically-produced protein hydrolysate from legume grains. Agric. 2017;7:1-9. https://doi.org/10.3390/ agriculture7080062.

57. Kiliç E, Puig R, Baquero G, Zengin G. Carbon footprint and energy balance of biodiesel produced from tannery fleshings. J Am Leather Chem Assoc. 2014;109:296-305.

58. Pringle T, Barwood M, Rahimifard S. The challenges in achieving a circular economy within leather recycling. Procedia CIRP. 2016;48:544-9. https://doi. org/10.1016/j.procir.2016.04.112.

59. Puig R, Cervantes G, Rius A, Marti E, Sole M, Riba J. Industrial ecology in the Catalan leather industrial clusters. Afinidad. 2008:65:423-9.

60. Daddi T, Ceglia D, Bianchi G, de Barcellos MD. Paradoxical tensions and corporate sustainability: a focus on circular economy business cases. Corp Soc Responsib Environ Manag. 2019;26:770-80. https://doi.org/10.1002/csr. 1719.

61. Gonzalez-Quijano G. The 60th John Arthur Wilson memorial lecture: a future for leather! J Am Leather Chem Assoc. 2019;114:244-55.

62. Gül S, Spielmann M, Lehmann A, Eggers D, Bach V, Finkbeiner M. Benchmarking and environmental performance classes in life cycle assessment-development of a procedure for non-leather shoes in the context of the product environmental footprint. Int J Life Cycle Assess. 2015; 20:1640-8. https://doi.org/10.1007/s11367-015-0975-7.

63. Moktadir MA, Rahman T, Ali SM, Nahar N, Paul SK. Examining barriers to reverse logistics practices in the leather footwear industry. Ann Oper Res. 2019. https://doi.org/10.1007/s10479-019-03449-y.

64. Pande B, Kumar AG. A Value Chain Framework for Assessment of Sustainable Practices in Manufacturing Firms. Eur J Sustain Dev. 2019;8:95107. https://doi.org/10.14207/ejsd.2019.v8n3p95.

65. Arroyo I, Cervantes G. Water footprint of an industrial product: An adapted methodology | Artículo Huella hídrica de un producto industrial: UNA metodología adaptada. Tecnol y Ciencias Del Agua. 2018:9:70-90. https:// doi.org/10.24850/j-tyca-2018-06-03.

66. Cimatti B, Campana G, Carluccio L. Eco design and sustainable manufacturing in fashion: a case study in the luxury personal accessories industry. Procedia Manuf. 2017;8:393-400. https://doi.org/10.1016/j.promfg. 2017.02.050

67. Chen J, Cheng B, Sun S, Zhang X. The influence of research of leather's ecological properties on its products-eco-design. J Soc Leather Technol Chem. 2014;98:275-84.

\section{Publisher's Note}

Springer Nature remains neutral with regard to jurisdictional claims in published maps and institutional affiliations.

\section{Submit your manuscript to a SpringerOpen ${ }^{\circ}$ journal and benefit from:}

- Convenient online submission

- Rigorous peer review

- Open access: articles freely available online

- High visibility within the field

- Retaining the copyright to your article

Submit your next manuscript at $\boldsymbol{\nabla}$ springeropen.com 